\title{
THE INFLOW OF RUSSIAN CAPITAL AND INDUSTRY INTO THE BUKHARA EMIRATE IN THE LATE 19TH AND EARLY 20TH CENTURIES
}

\author{
Fayzulla Ochildiev
}

Associate Professor, National University Of Uzbekistan Named After Mirzo Ulugbek, Uzbekistan

\section{ABSTRACT}

Beginning in the 80 years of 19 th century , the Russian government and entrepreneurs began to invest in the development of protected and gray lands in the emirate, as well as in the expansion of cotton fields. It also introduced an industry related to the processing of raw cotton grown in the emirate. It also pursued a policy of relocating the military and Russian citizens to major cities in the emirate.

KEYWORDS: - Emirate of Bukhara, Russia, industry, partnerships, joint stock companies, factories, silk, cotton gin, karakul leather, wool, ruble, telegraph.

\section{INTRODUCTION}

The end of the XIX century To the beginning of the XX century in the Emirate of Bukhara were established a number of friendly and joint-stock companies of Russia and Europe. These societies were engaged in the construction of cotton gins and oil mills in the emirate, as well as the purchase of products such as cotton, astrakhan leather, wool, and silk.

In the early twentieth century, a number of shopping centers and societies were established to purchase cotton and export it to Russia. In particular, the Eastern Bukhara Society, the Russian Society and the Caucasus Mercury Society in the Emirate were engaged in the purchase of cotton and sent large quantities of cotton to Russia[1].

The Russian-Bukhara trade and industrial partnership initially had a capital of 2.25 million rubles. Half of these funds went to the Bukhara government and half to the Ivan Stekheev and KO Friendship Society. The company mainly built and financed mills, factories, mills and trade enterprises in the Bukhara Emirate[2].

The Russian government is beginning to pay more attention to the development of cotton and karakul farming in the emirate. As a result, cotton fields expanded, and there were problems in processing the raw material grown and transporting it to Russia. He began to focus primarily on the construction of ginneries, which were associated with cotton growing. At the same time, oil mills, wool, silk, leather, and intestinal processing plants and enterprises began to cooperate.

In 1890, the first in the emirate, a large ginnery was built in the new Bukhara by the large Yaroslavl manufactory and the MG Falaksman 
CURRENT RESEARCH JOURNAL OF HISTORY 2(6): 20-26, June 2021

DOI: https://doi.org/10.37547/history-crjh-02-06-05

ISSN 2767-472X

(C)2021 Master Journals

\section{Crossref dof 80 Google}

Accepted 11 ${ }^{\text {th }}$ June, 2021 \& Published $16^{\text {th } J u n e, ~} 2021$

Friendship Society. After that, N.V. Kiseleva built and put into operation a meat processing and crushing plant in Chorjoi[3]. The products of this plant are completely exported abroad. Many grape varieties were grown in the horticulture, which led to the construction of wineries in the emirate.

For example, General M.G. Annenkov built a winery in Karakul. Also, in 1893, new wineries were built in Bukhara, Yakatut, Kyzyltepa and Chorjoi, and lemonade factories in Termez and new Bukhara[4]. After the migration of Russian citizens to the cities of the Emirate and the establishment of Russian villages, a winery was also built in Karakol by a French citizen Goethe [5].

\section{DisCusSiON}

In 1899, L.N. Levin, I.N. Sharipov and Belyak on the Kiziltepa, and Gutsevich in Karmana built ginneries near the Karakol station. The cost of ginned cotton in ginneries was much cheaper than hand-ginned cotton, at 60 pounds per pound. It was also possible to gin large quantities of cotton at ginneries.

In 1902, an oil refinery was built and put into operation in Merv and Karki. These plants had a production capacity of 5,000 pounds of oil per year [6]. In 1902, another large oil mill was put into operation in Murgab, which had the capacity to turn 4,000 pounds of seeds into oil per day. An oil refinery was also built in New Bukhara by the Great Yaaraslovl Manufactory and the M.G. Volksman Friendship Society, which had the capacity to oil 3,600 pounds of seeds per day [7].

Construction of ginneries in the Emirate grew rapidly. In 1905, there were 9 ginneries in the Emirate, which could process $2,500,000$ pounds of cotton during the season. 3 of them were built in the new Bukhara [8].

During the First World War, the number of ginneries in the Emirate of Bukhara increased. Cotton ginning plants were built in Old Bukhara, Gijduvan, Chorjoi, Zirbulak and other places. These ginneries were able to gin 2 wagons of local cotton and as much American cotton per day [9].

In old Bukhara in 1904-1908 VG Durshmidt, Pushnyanesko and Ibragimov built a gut recleaning plant. They also had a wool cleaning shop, a clover seed cleaning machine, and a flour mill in old Bukhara. The annual turnover of these entrepreneurs amounted to 250-300 thousand rubles [10].

Also in the old Bukhara L. Zalm, Kilma and $\mathrm{K}^{\circ}$, as well as Polish tanneries, and a tannery near Ziyodin station[11]. The hides processed in these mills were completely exported. As a result of the expansion of cities in the emirate and the construction of new cities, more than 10 brick factories were built and put into operation[12]. Davronov Khushvakhtsho notes that before the First World War there were about 60 factories and enterprises in the Bukhara Emirate, and later their number increased to 70 .

A.I. Ishanov acknowledged that before the First World War, more than 60 factories, enterprises and various societies were operating in the Bukhara Emirate by the Russian government and entrepreneurs. For example, in the Emirate of Bukhara "Eastern Joint Stock Company", "Russian Transport Company". There were jointstock companies such as the "Caucasus and Mercury Company", "Gerard and Gay". These societies served the merchants of Russia and Bukhara in the sale and purchase of products [13].

The seasonal operation of ginneries in the Bukhara Emirate began in August-September. He worked from March to April when the harvest was good and from January to February when the harvest was not good. The working season of the plants was 155-160 days. One machine could 
CURRENT RESEARCH JOURNAL OF HISTORY 2(6): 20-26, June 2021

DOI: https://doi.org/10.37547/history-crjh-02-06-05

ISSN 2767-472X

(C)2021 Master Journals

\section{Crossref do) 81 Google}

Accepted 11 ${ }^{\text {th }}$ June, 2021 \& Published $16^{\text {th } J u n e, ~} 2021$

gin up to 33 pounds of cotton fiber in a $12-13$ hour workday. In factories, one machine had the capacity to gin about 5,000 pounds of cotton during the season. One person could manually clean 10 pounds a day and 100 pounds during the season [14].

In the Emirate of Bukhara, most production facilities are located in Russian-populated cities. According to the data, until 1916 in Termez there were more than 30 trade and industrial enterprises related to the cotton industry, which were at the disposal of Russian and Bukhara entrepreneurs[15].

In 1912 in Termez there were several trade and industrial enterprises, including:

1. "Eastern Society of Warehouse Insurance, Transportation and Lending" (which had 6 employees: 5 of them were Russian citizens, 1 of them was from Bukhara, 4 of them one was Muslim, 2 were Orthodox, 2 were uzbeks, 2 were Tatar, and 2 were Russian);

2. Termez Court of the Caucasus Mercury Society (there were 6 employees in this court: 5 Russian citizens, 3 Muslims, 2 Orthodox, 1 Jew and 1 Turkmen)[16];

3. Engineer AG Ananev's ginnery (a total of 37 workers worked at the plant: 26 Russians, 3 Bukhara, 8 Iranians, 23 of them Orthodox, 13 Muslims, 1 Lutheran, 22 Russians , 8 Persians, 3 uzbeks, 2 Ossetians, 1 German, 1 Montenegrin)[17];

4. The Makhanbaev brothers' ginnery (all 13 workers at the plant are Russian citizens, including 10 Orthodox, 3 Muslims, 9 Russians, 1 uzbek, 1 Tatar, 1 Tajik, and 1 qualified citizen. worked); 5. "K.Sh.Shamsuddinov and K0 company ginnery" (initially the number of employees was 12, all Russian citizens, 7 Muslims, 5 Orthodox, 7 Tatars, 5 Russians) was built and put into operation [18].
In the development of light industry in Bukhara was a leader in silk weaving. There are 46 silk weaving shops in Bukhara, which employ a total of 197 people. The products they made cost 100,000 balls, with a total value of half a million rubles. This accounted for half of the silk woven in Central Asia [19].

T.G. Tukhtametov noted that at the beginning of the XX century in the Emirate of Bukhara there were 35 cotton gins, 3 oil mills, 3 intestinal plants, 3 licorice (etmak) root grinding plants, 1 wool cleaning plant [20].

These factories were distributed throughout the emirate as follows: 12 ginneries and 1 oil mill in New Bukhara[21], 6 factories in Chorjuy, including 3 gins, 1 oil mill, 1 licorice mill, 1 wool ginnery, 1 in Karakol. ginnery, 2 ginneries at Kyzyltepa station, Mustafa khoji ginnery in old Bukhara, 3 ginners in Karmana, 2 ginners in Ziyavuddin, 4 ginners in Karki, 2 ginners in Termez, 1 There was an oil refinery, 1 gin in Gijduvan, 2 gins in Zirabulak, and 1 gin in Jillikul[22].

Davronov notes that before the First World War, there were 27 ginneries in the Bukhara Emirate, of which 20 belonged to Russia, 3 to the Emir of Bukhara, 4 to local entrepreneurs, and 1 to Mirza Muhiddin Mansurov.

A.I. Ishanov writes that before the First World War, the emirate had 26 ginneries, a ginnery and oil mill in Kogan, a total of 15 factories and enterprises in the railway workshop, 10 factories in Chorjoi, a workshop of the Amudarya flotilla and other manufacturing enterprises [23].

A.P.Fomchenko at the beginning of the $\mathrm{XX}$ century in the new Chorjoi more than 300 different trade enterprises, more than 10 factories, railway workshop, Amudarya flotilla office, military chief's office, finance, Russian school, dispensary, post and telegraph office, customs departments, in New Bukhara. (Kogan) 
CURRENT RESEARCH JOURNAL OF HISTORY 2(6): 20-26, June 2021

DOI: https://doi.org/10.37547/history-crjh-02-06-05

ISSN 2767-472X

(C)2021 Master Journals

\section{Crossref dof 80 Google}

Accepted 11 ${ }^{\text {th }}$ June, 2021 \& Published $16^{\text {th } J u n e, ~} 2021$

stated that 7 cotton gins, oil and wine factories, and a tobacco factory of economic importance have been put into operation [24].

\section{Result}

During this period, in the Russian-populated cities of the Bukhara Emirate, one could find many shops associated with trade. For example, in Termez there are large shops of Shalman, Bakhtadze, Mgaloblishvili, Avanov, Karimov, Akhnazarov, Aganosov, Aryutyunov, Ayrapetov, Gozarov and Davidov, which sell a variety of imported industrial goods[25].

Russian citizens and officials were also involved in gold mining in the Bukhara Emirate. In 1894, mining engineer Jorovko Pokorsky came to East Bukhara in search of gold-bearing areas. He then asks the government for permission to search for gold in the Yah-Su, Safetdarya and Mozorsuv areas[26]. On February 24, 1896, he received permission from the Russian government to mine gold. In 1896-1899, he mined more than 2 pounds of gold along the Safetdarya.

In 1901-1909, G.A. Sirass conducted gold mining in the territories of the principalities of Darwaz and Baljuon[27]. Russian General Pokotilo has also been involved in gold mining for 10 years, handing over 32 pounds of gold to the Bukhara government [28]. N.N. Levashev and Moiseenko were also engaged in gold mining for some time in the Darvaz principality[29].

At the end of the 19th and the beginning of the 20th centuries, the Russian Empire partially repaired the emirate's internal roads and carried out a number of construction works[30]. For example, paved roads were built and repaired from Charjou to the border of Khiva, KarshiGuzar, Kalif, from Charjoy-Karki, from Guzar through Darband to Sherabad and Termez, from Samarkand to Termez. In eastern Bukhara, a number of trade routes were repaired and rebuilt at the expense of Russian capital. In 1900, a road was built from Termez to Kulob, which was convenient for horse-drawn carriages.

At the beginning of the 20th century, at the initiative of Russian entrepreneurs, at the expense of the Emir of Bukhara, they began to build a telegraph line and postal telegraph offices in the emirate. The telegraph line connected the cities of Kattakurgan with Bukhara, Kalif, Charjou, Kerki, Patta Gissar, Samarkand, Termez, Karshi, Guzar, Kitab[31].

As a result of the telegraph line, post and telegraph offices were built and put into operation in Bukhara, the new Bukhara (Kogon), Shakhrisabz, Guzar, Karshi, Sherabad, Kulob, Saray, Chorjoi, Karki, Kalif and Termez[32]. In 1902, the Sherabad Joint Stock Company allocated 277,000 rubles for the post office and telegraph in Termez [33]. Thus, all cities in the emirate were able to communicate with any city in Russia.

Beginning in the 1980s, the Russian government and entrepreneurs began to invest in the development of protected and gray lands in the emirate and the expansion of cotton fields.

The Russian government has sent specialists to the Emirate of Bukhara to conduct research to expand cotton fields and develop new lands. They presented their findings to the Russian government.

Until the 1980s, the emirate was planted with local cotton, and from 1888, the emirate began to grow American cotton. By the beginning of the twentieth century, the area under cotton in the Bukhara Emirate expanded significantly. By 1901 , the area under cotton had reached 65,000 acres, and by 1915 , the area under cotton had reached 100,000 acres, of which 51.3 acres had been planted with American cotton. By this time, the area under cotton in the emirate had increased fivefold[34].

In the Bukhara Emirate, farmers faced major 
obstacles in planting and selling cotton. One of the main obstacles was the dyeing system, in which the usurers gave the dye to the farmers and demanded that they return the dye with cotton instead of cash. At the end of the 19th and the beginning of the 20th centuries, a number of friendly and joint-stock companies of Russia and European countries were established in the Bukhara Emirate. These societies were engaged in the construction of cotton gins and oil mills in the emirate, as well as the purchase of products such as cotton, astrakhan leather, wool, and silk.

\section{Conclusion}

The Russian government has been paying great attention to the development of cotton and karakul farming in the emirate. As a result, cotton fields expanded, and there were problems in processing the raw material grown and transporting it to Russia. In order to overcome the problems that arose, the government began to focus on the construction of ginneries related to cotton. At the same time, they began to build factories and enterprises for processing oil, wool, silk, leather, and intestines.

In the Emirate of Bukhara, ginneries and other industrial enterprises were built in Russianpopulated cities such as Old Bukhoro, Termez, Gijduvan, Chorjoi, Zirbulak. The work done by the Russian government and businessmen in the Emirate is primarily from an imperial point of view.

At the end of the 19th century and the beginning of the 20th century, the internal roads of the emirate were partially repaired and a number of construction works were carried out.

\section{RefERENCES}

1. National archive of the Republic of Uzbekistan, 1 fund, 1 list, 12 works, 2 sheets.
2. National archive of the Republic of Uzbekistan, 3 funds, 2 lists, 440 cases, 50-52 pages

3. Tukhtametov T.G. Russia and the Emirate of Bukhara at the beginning of the XX century :Dushanbe., 1977 .-. P-122.

4. Khakimova K.Z The peasantry of the Bukhara Emirate at the end of the XIXbeginning of the XX century. -T .: Fan, 1991.P.74.

5. National archive of the Republic of Uzbekistan, 2nd fund, 1st list, 24th work, 1st sheet.

6. National archive of the Republic of Uzbekistan, I-1 Fund, 11th List, 1372 Case, 16th Sheet.

7. Khakimova K.Z., Kravets L.N. Socioeconomic relations and class struggle in prerevolutionary Uzbekistan. T. - 1980.P. 73.

8. Gubarevich Rodobylsky A. Economic sketch of Bukhara and Tunisia. SPb. 1905.P. 73-74.

9. National archive of the Republic of Uzbekistan, I-3 Fund, List 1, Case 563, 13th Sheet.

10. National archive of the Republic of Uzbekistan, I-3 Fund, List 1, Case 424, Sheet 19.

11. National archive of the Republic of Uzbekistan, I-126 fund, list 2, case 703, sheet 2.

12. Tukhtametov T.G. Russia and Bukhara emirate in the beginning of XX century.Dushanbe., 1977.P-123.

13. Ishonov A.I. People Republic of Bukhara. Tashkent. 1969.P.79.

14. National archive of the Republic of Uzbekistan, I-3 Fund, List 1, Case 1372, Sheet 16. 
CURRENT RESEARCH JOURNAL OF HISTORY 2(6): 20-26, June 2021

DOI: https://doi.org/10.37547/history-crjh-02-06-05

ISSN 2767-472X

(C)2021 Master Journals

Crossref dof 81 Google

Accepted 11 ${ }^{\text {th }}$ June, 2021 \& Published $16^{\text {th } J u n e, ~} 2021$

15. Ochildiev, F. B. (2008). Socio-political and economic changes in the principalities of the Surkhandarya oasis. P.107-117.

16. National archive of the Republic of Uzbekistan , I3-fund, 1-list, 437-work, 17sheet.

17. National archive of the Republic of Uzbekistan, I3-fund, 1-list, 437-work, 18sheet.

18. Ochildiev, F. B. (2008). Socio-political and economic changes in the principalities of the Surkhandarya oasis. P.107-117.

19. National archive of the Republic of Uzbekistan, R-47 Fund, List 1, Case 115A, 29 Sheets.

20. Tokhtametov.T.G. Russia and the Bukhara Emirate in the early twentieth century. Dushanbe. 1977. P.121.

21. National archive of the Republic of Uzbekistan, 1 fund, 12 lists, 2079 cases, 1-7 pages

22. Tokhtametov .T.G. Russia and the Bukhara Emirate in the early twentieth century. Dushanbe. 1977. P.123.

23. Ochildiev, F. B. (2019). THE CREATION OF THE AMUDARYA FLEET. Theoretical \& Applied Science, (10), 583-586.

24. Fomchenko A.P. Russian settlements in Bukhara Emirate Tashkent.1958. P.14-15

25. National archive of the Republic of Uzbekistan, Fund 3, List 1, Case 181, page 57.

26. Ochildiyev, F. (2019). TRADE RELATIONS BETWEEN BUKHARA AND RUSSIA IN THE SECOND HALF OF THE XIX CENTURY-THE BEGINNING OF THE XX CENTURY//Social Sciences: Achievements and Prospects Journal 3 (11), 2019/OEAPS Inc.(Open European Academy of Public Sciences);
Chief Editor Mark Freeman-Barcelona, Spain. 16.03. 2019: OEAPS Inc., 2019.-pp. 55-60.

27. Tukhtametov T.G. Russian and Bukhara relations in XIX-XX century. T.1966.P.125.

28. National archive of the Republic of Uzbekistan, I-3fund, List 1, Case 259, 7th Sheet

29. Tukhtametov T.G. Russian and Bukhara relations in XIX-XX century. T.1966.P.126.

30. Tukhtametov, T. Russia and the Bukhara Emirate at the beginning of the twentieth century. - Dushanbe. 1977. p. 71.

31. Tukhtametov T.G. Russian Bukhara relations at the end of the XIX - beginning of the XX century T. 1966. P.108.

32. National archive of the Republic of Uzbekistan, I-2, list 1, case 330, 2-6 pages.

33. National archive of the Republic of Uzbekistan, I-3fund, List 1, Case 678, Sheet 319.

34. FayzullaOchildiev, (2021). Cotton Production Development In Bukhara Emirate During The Late XIX - Early XX Centuries. The American Journal of Social Science and Education Innovations, 3(02), 119-125.

35. Парманов, Ш. Э. (2017). ИЛК ЎРТА АСРЛАР ДАВРИ СЎҒД ШАХАРЛАРИ ТАРИХИДАН. Научная дискуссия: вопросы социологии, политологии, философии, истории, (6), 40-45.

36. МУХАМЕДОВ, Ё. (2021). ЧОЧ ХУКМДОРЛИГИНИНГ СИЁСИЙМАЪМУРИЙ БОШҚАРУВИ ТАРИХШУНОСЛИГИ. In Uzbek Conference Publishing Hub (Vol. 1, No. 01, pp. 508-512).

37. Muhamedov, Y. K. (2019). The history of commercial economical-cultural relations of 
CURRENT RESEARCH JOURNAL OF HISTORY 2(6): 20-26, June 2021

DOI: https://doi.org/10.37547/history-crjh-02-06-05

ISSN 2767-472X

(C)2021 Master Journals

Crossref doi) 81 Google

Accepted 11 th June, 2021 \& Published 16 th June, 2021

Tashkent oasis. ISJ Theoretical \& Applied

Science, 10 (78), 579-582. 